\title{
Travel, Politics and the Limits of Liminality During Australia's Sixties
}

\author{
Jon Piccini, University of Queensland
}

\section{Introduction}

In 1968, Brisbane student activist Brian Laver travelled behind the 'Iron Curtain.' A leading member of the University of Queensland student activist group Society for Democratic Action (SDA), Laver's trans-continental sojourn was inspired by a desire to both understand and declare his solidarity with a global wave of youth rebellion that rejected not only the Cold War divide between the free and communist worlds but the tired politics of the 'old left' that he increasingly rejected. Despite making stopovers in London, Paris and other hotspots, it was in the perhaps unlikely destination of Prague, Czechoslovakia that Laver was to have a life changing experience. The country was undergoing a process of democratisation and debate known as the Prague Spring that excited foreign, including Australian, observers with its 'third way' to socialist democracy and new freedoms of expression and assembly. As Laver explained upon his return:

\footnotetext{
When we arrived there in late July what impressed me was the vitality of popular expression and participation in the events unfolding. Prague was alive with meetings. In one square meetings went on for 16 hours a day; they had begun before we arrived in Czechoslovakia and were still [going] one month after we returned from Bulgaria. In fact, I was in this park the night the invasion began talking to a group of East German students committed to revolutionary struggle against the Ulbricht bureaucracy. (1969:2)
}

It was, as he declared, 'perhaps the freest expression of social communication I have ever lived through' (2). This moment, one that anthropologist Victor Turner would term liminal — where the ordinary structures of society evaporate in favour of one which is 
'anti-hierarchical, democratic, and full of potential for transformation' (Jobs 2009: 402) — had a profound impact on Laver's activism, and that of his contemporaries.

Experiences such as Laver's frame both this paper and the broader research project from which it arises - locating Australia within the emerging field of transnational Sixties studies. Previous scholarship of these global connections, almost always those of an inter-European or trans-Atlantic perspective, have illustrated ideological and organisational networks between activists in the USA or Canada with those in Cuba, West Germany, France or Czechoslovakia, amongst others. ${ }^{1}$ What is only now becoming a real point of concern, however, is the physical movement of activists across borders, often read through the frame of what Turner labels communitas - a moment defined as much by 'an intense and spontaneous community spirit of equality, fraternity, and solidarity' as it is by fleetingness and, arguably, inconsequence (Jobs 2009: 402). While unpacking ideas of pilgrimage, liminality and communitas in the context of Australian Sixties radicalism, this paper will foreground the importance of a wider temporal dimension - the ideas, imaginings and events that motivate travel as well as the translations and debates that occurred in its aftermath—resuscitating travel as a thoroughly historical (and hence political) category.

While previous work on Australian social movements has often highlighted the importance of global ideas, particularly around race, anti-colonialism and black power (Clark 2008; de Costa 2006; Lothian 2005) and the ways in which these ideas were transmitted and translated into a new local context (Scalmer 2002), only rarely are the productive exchanges of people across borders explored. This is a strange omission, when one considers that an Australian radical returning from overseas often received an elevated place within the movement - able to communicate ideas and practices from abroad with more authority than those who had merely read of them, or glimpsed them on television. The circulation of these images and texts, while vital to the development of a global imaginary, was extended and complemented by 'pilgrims' who sought to directly encounter these ideas and practices, hence making their lessons more understandable and transferable to a new context. As Scalmer describes those travellers who encountered and translated Gandhism, '[t]heir personal experiences granted confidence and authority, their direct and sometimes intimate contact ... served to

\footnotetext{
${ }^{1}$ See for example, Klimke (2010), Varon (2004), Gosse (1993) and Brown (2009).
} 
legitimate as well as instruct' (2011: 103). Through a focus on three travel narrativesthose of Laver and other young radicals to Eastern Europe in 1968, Denis Freney to Algeria in the early 1960s, and five Indigenous activists to a Black Power conference in Atlanta in 1970 - the uses and limits of travel as both political praxis and focus of historical enquiry will be explored, revealing an overlooked group of Australians abroad.

Travel became an increasingly central part of culture and politics throughout the 1960s. The decade from 1961 saw rates of departure amongst the 20-24 age group increase more than six fold, with older age brackets not far behind, while a survey of some 100 radicals at the University of Queensland found that 57 percent placed overseas travel as their main post-graduation ambition. ${ }^{2}$ In contrast with older generations of political travellers to the Soviet Union during the inter-war years, whose purpose was most often to project Party myths and distortions back home, these travellers took a more critical and wider ranging set of positions. ${ }^{3}$ As Jobs (2009: 376-77) relates in his work on intraEuropean travel during 1968, middle class youths 'created interpersonal solidarities ... that emphasized mobility and built a shared political culture across national boundaries.' The post-war boom, proliferation of communication technology and the growing affordability of air travel facilitated these sorts of movements. Twenty-two year old Richard Holmes, a recently graduated university student living in a communal flat in London, saw and read of events in France during May '68 on TV and newspapers. He soon started to receive letters from friends already there 'speaking in confused, rapturous terms of the long "sit-ins," the great marches and demonstrations, people coming from all over Europe-Berlin, Rome, Amsterdam — to celebrate the new spirit of liberté, and take part in some huge, undefined événement' (Jobs 2009: 377). This 'new community of hope' was, for Holmes, only a channel away. Yet, for Australian activists located on 'the fringe of the world' (Scalmer 2011: 2), integration into these imagined communities was a very different undertaking.

Those scholars with a bias toward such European and trans-Atlantic itineraries often also fail to acknowledge the importance of connections between third world locations or colonised peoples and the first, developed world. Such connections and associations

\footnotetext{
${ }^{2}$ Between the years 1961 and 1971, the number of departures amongst the 20-24 age group increased from 8,976 to 53,683. See Sobocinska (2010: 196). On University of Queensland radicals, see Rootes (1969: 237-38)

${ }^{3}$ For further comment on Australian travellers to the USSR, see Fitzpatrick and Rasmussen (2008).
} 
were, however, vital. Judy Tzu-Chun Wu (2007: 577) explains how travel by first world visitors to sites of third world dissent 'facilitated international exchanges of ideas that ... fundamentally shaped [their] political understanding, identities, and agendas,' while Gildea, Mark and Pas (2011: 450) describe how such encounters 'provided a new and powerful model of revolution for European radical activists.' Trends towards decolonization and national liberation, often framed around discourses of blackness, additionally saw an explosion of collaborations across the 'third world,' developments often ignored in studies that explore 'the center and the margin but rarely examine the relationships among different margins' (Lionnet \& Shih 2005: 2). Everything from the Bandung conference in 1955 to the third world's infatuation with Castro's 1959 Cuban revolution and the Congress of African Peoples in the 1970s display these anti-colonial transnational connections that existed without the need for a Western referent. ${ }^{4}$ Similarly, travel by White Australians and Indigenous activists to third world destinations or the 'internal colonies' of the metropole had an important and largely unacknowledged impact on 'Australia's Sixties.'

\section{Imagining global connection}

While the global unrest characteristic of 1968 was a hot topic in Australia, both in the mainstream and the developing radical or underground press, many dismiss this interest as superficial and never amounting to sustained concrete action. As commentator Hugh Mackay opines, Australians may have been 'intrigued, saddened, even alarmed' by the traumatic events of the period—ranging from the assassination of Martin Luther King to the Russian invasion of Czechoslovakia- 'but [were] not really engaged' (Mackay 2009: 74). Radical sycophancy with (largely American) protest ideas and practices are seen as conceited and largely irrelevant in this narration, with the progressive Whitlam Labor government of 1972-1975 the only period of real change. ${ }^{5}$ Critical minorities, who were very active from the late 1950s onward, are excluded from this version of events. Whether campaigning around local concerns such as Aboriginal disadvantage and labour issues, or those like Vietnam and South Africa of a more global nature, the

\footnotetext{
${ }^{4}$ For examples of this scholarship, see Frazier (2006), Young (2006), Wilkins (2006) and Joseph (2001-2).

${ }^{5}$ One work that attempts to challenge this conception, Donald Horne's Time of Hope (1980), presents the period from 1966 through to 1972 as one which facilitated Whitlam's election, while still ensuring its role as key referent. However, like most works, it treats political social movements as largely irrelevant, preferring to articulate broader social and cultural shifts in permissiveness, 'youth,' and so on. While some work does exist that takes Australian 'Sixties' radicalism seriously (Russell 1999; Yeats 2010; d'Avigdor 2011; Clark 2008, for example) none of these texts seek to understand the role of physical movements across borders in these events.
} 
foundations for the radicalisation of 1969 and 1970, were laid well before, often by globally mobile individuals who imagined beyond the narrow parameters and cultural cringes of the 'lucky country.'

Activists became part of this 'imagined community of global revolt' in local, specific contexts (Prince 2006: 851). Brian Laver was one of a small activist community at the University of Queensland who, inspired by the writings of American group Students for a Democratic Society (SDS), decided in August 1966 to form a like-minded organisation seeking to bring 'social reality...into line with the liberal rhetoric' (O'Neill 1969: 9). Émigré American Ralph Summy, who came to Australia after facing political pressure in the USA, provided much of the literature produced by SDS. Everything from copies of their newspaper to the famous Port Huron Statement and other pamphlets were consumed and reproduced in large numbers by these budding radicals. SDA's borrowings were self-conscious, stating their allegiance with 'the American student's concept of "grassroots democracy" (Society for Democratic Action leaflet 1966) and mirroring SDS's early politics of anti-anti communism - exhorting the West to 'stop the spread of communism by proving democracy is better' (Vietnam Protest Week leaflet 1966). The group proceeded to organise a civil liberties campaign, inspired both by the local realities of a conservative government and police repression against anti-Vietnam war protestors, as well as the well-publicised example of Berkley's Free Speech Movement. In September 1967 SDA mobilised half the student population for a massive march and rally that took over central Brisbane city streets demanding the right to march and the alteration of traffic laws used to curtail free speech (O'Neill 1969: 11).

The group's next major capture of urban space, a more long term project of establishing a youth political-cultural club on the third floor of Brisbane's Trades Hall, illustrates the radicalising and de-Americanising global imaginary of these activists. Named 'Foco,' after Che Guevara's strategy of setting up liberated zones in hostile terrain, the club featured a popular rock band and a host of political-cultural events that made it a veritable landmark for its yearlong existence. A bookstall—'the most radical literature you've ever seen' (Laver 2001)—graced the entry, while a room was set aside for

\footnotetext{
${ }^{6}$ The Traffic Act was used by the Queensland State Government to control access to public spaces for the means of protest. All applications for public demonstrations had to be made under this legislation, which additionally charged a rather steep one-dollar fee for the holding of a placard (Prentice 2007: 27).
} 
poetry and drama and another for film, which played documentaries on North Vietnam or protest movements around the world as well as rarely glimpsed European avant-garde productions. Regular discussion groups featured everyone from an American civil rights campaigner to a DJ who lectured on the politics of pop music (Piccini 2010: 9).

Foco's radicalised space reflected SDA's transformation from a relatively liberal protest group to one framed by the increasing militancy of the European radicals. The 19 March 1968 issue of Student Guerrilla (1968a: 1), SDA's new weekly campus newssheet, announced that 'Marx has been found again. Not sitting in the London library among the archives, but in the classrooms of Poland [and] Czechoslovakia,' rebelling against Soviet authoritarianism. The shooting of famed West German radical Rudi Dutschke by a right wing fanatic on 11 April 1968 - only a week after Martin Luther King's assassination — saw the distribution of a campus leaflet announcing: 'Yesterday King, Today Dutschke, Tomorrow Us,' a clear indication of the radical's multiplying overseas affinities (Student Guerrilla 1968b: 1). This growing fascination drove Laver abroad, where he would meet 'most of the world leaders of the struggle' and bring back lessons that could connect SDA with Europe's growing radical zeitgeist (Foco Newsletter, 20 November 1968). Many other Australian radicals shared such complex and incomplete readings, described by one traveller as 'a confused kaleidoscope of impressions' (Mortimer 1976: 118). Melbourne student radical Michael Hyde (2010: 75-76) framed his 1968 trip to China around one particular image. 'China,' Hyde explained, was '[h]ome of the Cultural Revolution [and a] socialist society that had been forged in the struggle against imperialism, led by one of the people stuck on my bedroom wall.'

Twenty-five year old teaching graduate Dennis Freney, provides a similar, if perhaps more studied, impression of his motivations. Born to a left wing Catholic family during the Great Depression, he joined the Labor Party at age 16, and the Communist Party of Australia (CPA) at the height of the Petrov Affair - only to be expelled three years later for association with Trotskyists. Freney's was a moment framed by the end of one transnational fantasy: the Soviet Union, with Nikita Khrushchev's secret speech and the bloody invasion of Hungary shattering the illusions that he and many other Australian intellectuals had in Moscow's increasingly wayward project. Describing these events as an 'unpleasant surprise,' he soon began discussing with a small group of Party members as to whether they might 'reflect more deep-rooted deficiencies in the Soviet system' 
(Freney 1991: 86-87), activities that would lead to his expulsion by a feverishly proRussian leadership. Joining the local Trotskyist Fourth International group some time later-whose miniscule numbers belied their imagined position as legitimate guardians of Lenin's legacy against a monolithic Stalinism-Freney was invited to the organisation's 1961 global conference as the Australian section's representative.

Freney explained how he "was excited at the possibility of meeting all these people whose articles I had so avidly read,' mostly in journals obtained from the voluminous library of local unionist and autodidact Nick Origlass. He also recalled, however, a desire "to do my own little "grand tour" of Europe, financed by a working holiday in London' as being high on his list of priorities (Freney 1991: 111-12). This mixture of politics and pleasure, though rare amongst the many Australians who took similar working visits to Europe during the period, should not be surprising. Freney, after all, labelled himself a 'revolutionary tourist,' showing how a number of seemingly contradictory imperatives and ideas could influence motivations for travel. Soon, however, Algeria became Freney's main focus. Achieving independence from France in 1962, the country had taken a strongly leftist hue under the leadership of Ahmed Ben Bella, leader of the National Liberation Front (FLN). An association with Michel Pablo_-leading Trotskyist and proponent of 'third worldism, ${ }^{7}$ who was briefly incarcerated in Belgium for financing the FLN—saw Freney imagine the possibilities of supporting this seemingly new style of socialism, one which could perhaps avoid the mistakes characteristic of Stalinist Russia. 'If the Fourth International was to get anywhere,' he declared, 'it had to involve itself in a real revolution, and the Algerian Revolution was one such case in hand' (157).

The allure of a 'real revolution' was equally potent for the group of Indigenous travellers who visited the USA in 1970. The civil rights movement in Americadeveloping from the mid-1950s onwards - was taking up more space both in mainstream newspapers and the publications of Indigenous groups, while an unannounced visit by Bermudan 'Black Power advocate' Roosevelt Brown to Melbourne in August 1969 marked a significant turning point. Brown, described in one tabloid as a spruiker of 'racial violence ... and sickening fears' and in another as 'the

\footnotetext{
7 'Third worldism' (tiersmondisme) refers to a political outlook common amongst Sixties radicals which looked to national liberation struggles in the developing world as central to a global revolutionary strategy (Gildea, Mark \& Pas 2011: 449-51).
} 
most unwelcome visitor Australia has had for a long time,' was told in no uncertain terms to 'get out' by the Daily Mirror (Lothian 2002: 48). Despite such protestations, a small but growing group of young activists noted the effect that Brown's threat of Black Power seemed to elicit in the Australian psyche. Small circles of Indigenous activists in Sydney, Melbourne and Brisbane, tired of the gradualism of established organisations, were 'accelerat[ing] their international awareness' according to Redfern activist Gary Foley. They began to identify with Brown's call for black control of black affairs, Foley recalls, while 'demonstrations against the War in Vietnam bought together elements of black and white political activists' who began to share ideas 'influenced by the anticolonial movements in India and Africa ... and writers like Franz Fanon, Jean Paul Sartre and Camus' (Foley 2001).

Kathy Lothian (2005: 183) describes how these young urban activists found 'that the ideas and terminology of Black Power resonated with their own life experiences.' That the referendum of 1967, which had marshalled over 90 percent of voters in favour of eliminating the two most avowedly discriminatory clauses of the Australian Constitution, seemed set to change so little despite the seeming popular mandate, only served to fire their interest in such topics. Activist Bruce McGuinness commented that Stokely Carmichael and Charles Hamilton's Black Power, a foundational American text, 'should be a prized possession of every Aborigine,' while Foley described how 'Malcolm X exploded in my mind' after fellow activist Paul Coe lent him the AfricanAmerican radical's autobiography (Lothian 2005: 183). Thus, when an invitation arrived from Brown for five activists to attend the Congress of African Peoples - $a$ major Black Nationalist conference in September 1970 held in Atlanta, Georgia - the possibilities of immersing themselves further in a global network of black and Indigenous resistance 'tied together by poverty, oppression, skin pigmentation and the White Man's hatred' could not be passed over (de Costa 2006: 97).

These examples both reinforce and challenge Turner's conceptions. Prospective travellers undoubtedly felt a deep affinity with their global co-thinkers, whether from the USA, Czechoslovakia, Algeria or a multiplicity of other locations, and sought to immerse themselves in Prince's 'imagined community of global revolt' (851). However, if communitas is merely 'a flash of mutual understanding' (Turner 1982: 48), then what of these important pre-histories to the moment of encounter? These soon-to-be pilgrims 
had a variety of complex ideas and purposes that motivated their trans-continental desires, often framed as much by the local specificities of struggle as by the promise of a utopian experience.

\section{Communitas and the liminal moment}

Wharf labourer and Aboriginal activist Charles 'Chicka' Dixon crossed the heavily guarded border into 'Red' China in December of 1972. Despite initial trepidationlargely due to the plentiful armed border police-Dixon soon found himself immersed in the utopian China he was presented with. Here was a land where poverty and want were largely eliminated and where, unlike in his homeland, 'different cultures are regarded as precious' (WSA Leaflet 1973: 1). 'Nobody called us nigger, jackie or boong,' Dixon related in a less-than-subtle attack on Australia's enduring racism (1). His being treated 'for the first time like a man' seems to articulate a transnational connection that was truly liminal - 'betwixt and between routine social interaction' (Scalmer 2008: 246).

A similar feeling overcame Laver in his visit to revolutionary Czechoslovakia. An ability to converse, across undoubtedly difficult language barriers, with East German students through a shared discourse of socialist democracy and anti-Stalinism seems indicative of Turner's communitas. This experience of unbridled communication between all strata of society, 'ideas contained by twenty years of [Former Czechoslovak leader] Novotney suppression' (Laver 1969: 2), was however soon to clash with the everyday brutality of Stalinism as he embarked with the Czech delegation to the World Festival of Youth and Students in Sofia, Bulgaria. Billed as gatherings of the world's progressive youth, these events were actually an integral part of what is now termed the 'cultural Cold War.' The Soviet Union used them to attract 'as many future [world] leaders as possible to participate, to hear the Soviet story, and in so doing win them over to its camp' (Krekola \& Mikkonen 2011: 232). This agenda was challenged at the 1968 festival, with radical Western European youths and their Czech co-thinkers attending in large numbers. Laver arrived in Sofia aboard the Czechs' train, decked with combative slogans like 'Marx is alive in Prague' and 'Lenin must return to the Finland Station,' and received an understandably harsh reception. Their aims - a public articulation of faults in the Soviet system, its lack of democracy and stalled progress towards socialism — saw them 'treated badly' and having to contend with 'increasing problems 
of harassment by the Bulgarian authorities' (Laver 1969: 6). Czech students and their allies from the West were barred from holding informal gatherings, arrested in large numbers during an unauthorised march to the US embassy, and had pro-Chinese communist material confiscated, according to another Australian traveller (Taylor 1968: 9)

Young members of the Communist Party of Australia (CPA), who were increasingly aware of the need for anti-bureaucratic reform and a less Soviet-focused outlook, presented their experiences in a far more revelatory light. Party member Susan Burgoyne, who had served on the International Preparatory Committee for the festival in Sofia for several months prior to festivities beginning, noted in a controversial article upon her return how organisers refused to allow important questions, like the significance of Western European student movements and the political relationship between students and workers, to be discussed in depth. As such:

Informal debates and teach-ins were organised when many festival participants found themselves dissatisfied with the standard of scheduled discussions ... [These] spontaneous events were challenging and often produced a genuine unity amongst participants because this was a unity forged out of a desire to understand and learn. (Burgoyne 1969: 46)

This spirit of the encounter resonates with Turner's theorisation of pilgrimage. Arising from Christian lexicon, a pilgrim leaves the everyday inanities of life to experience "the basic elements and structures of ... faith in their unshielded, virgin radiance' (Turner \& Turner 1978: 15). The desire to travel to Europe - a global hotspot of revolution - to either experience new forms of militancy or pay homage to, and then critique, old ones, is clearly present in the accounts of both Laver and Burgoyne. What the pilgrim's unshielded experiences additionally allowed was the 'spontaneous ... unity' of Burgoyne's description, the 'feeling of kinship and equality with others' that Scalmer (2008: 246) defines as the core meaning of communitas. As Burgoyne (1969: 48) related: 'I was in a group of Czechoslovaks in Bulgaria on August 21 and ... was overwhelmed by their reaction to the occupation of their country ... It was gratifying for an Australian in Europe to be able to talk to people from Czechoslovakia and know that they were aware that the communists in Australia supported them.' A more spontaneous unity would be difficult to find.

If travel creates a space for such comradeship and solidarity, it additionally provides for the articulation of ideas, practices and subversive pleasures impossible in local contexts. 
Freney's trip to Algeria seems enlightening in all these respects. He was employed as a translator for both the revolutionary government's new press agency (a job he came to believe was 'invented for me' by the friendly government) and Pablo, who was assisting the government in realising its radical ideals of self-management (Freney 1991: 172). The collapse of Algeria's economy, owing to the flight of many French-Algerians after independence, saw workers and peasants take over much abandoned property and run it themselves - a spontaneous politics that the Algerian government claimed as its own. Freney noted that this not only 'provided a route towards the socialist and democratic transformation' of that nation, but if successful 'could become something of an example to the rest of the world' - even for the transformation of his homeland (168).

Its victory against colonialism and subsequent post-revolutionary enthusiasm also made Algeria an important site of pilgrimage for fellow third world revolutionaries, something the Australian traveller revelled in, regularly making acquaintance with Zimbabweans, Ethiopians and Angolans. Such open interaction carried over into Freney's personal life, with the liminality of overseas travel allowing exploration of his closeted homosexuality. Previously hidden due to fear that 'family, friends and comrades would discover my true desires,' Freney (1991: 178) explained how he felt '[m]y life as a world revolutionary would be impossible to sustain' if such a discovery were made. If travel provides possibilities for the reinvention and translation of global ideas in local contexts, then this change can also occur on a personal-political level, with Freney (1991: 178) relishing 'my newly discovered identity' nearly a decade prior to the heralding of Gay Liberation.

Perhaps the most clear cut of these pilgrimages was by the five Indigenous activistsBruce McGuinness, Pat Kruger, Bob Maza, Solomon Bellear and Jack Davis — whose report back presents their experiences as thoroughly liminal. The Congress of African People, to which Brown had invited them, was a cultural nationalist venture whose rallying cry of 'Black is Beautiful' and 'It's Nation Time' built both a sense of pride in and political solidarity between diverse 'black' or third world peoples (Frazier 2006: 147-48). The Congress was undoubtedly popular, attracting some 3000 delegates from around the world, including a number of Indigenous peoples without a distinct 'African' origin. The Australian delegates - none of who had previously ventured beyond Australia's shores-were soon surrounded by an inspiring array of Black Power 
organisations and leaders. Pat Kruger (1970: 31), the only female Australian delegate, recalls meeting everyone from 'the Harlem Youth Federation, the Black Panthers, Long Island CORE [and] the National Council of Negro Women' to representatives of recently decolonised African states.

It was more than this previously unthinkable array of representatives, however, that made the activists feel as if they had entered a liminal zone. The group's first experience of the United States was not the violence and hatred their readings of Australian newspapers had prepared them for, but rather a white woman and black man walking hand-in-hand. When taken to their hotel an even more astonishing event transpired, with a white porter scrounging for a tip their black hosts had let fall to the ground. 'I don't think it was intentional,' McGuinness (1970: 7) explained, 'but you should have seen that guy on his hands and knees picking up the nickels and dimes while us poor lowly coloured folk stood around watching' - a piece of theatre certainly outside of routine social interaction in Australia. Their fears around acceptance at the conference for not being 'black' enough were soon quashed, with McGuinness (1970: 8) noting that, despite the 'fairness of my skin' his fellow delegates 'showed me that I was like them and in the Black Bag.' Another delegate, Bob Maza (Gilbert 1973: 117), developed a similar feeling of solidarity with fellow delegates after being asked at a public meeting what the name for Australia was prior to European settlement. His simple reply of 'home' saw a 'pretty good rapport' develop between the delegates, all of whom shared a similar historical experience of oppression or dispossession that was finally being globally articulated.

\section{Translating and debating the global}

While the experience of overseas travel is obviously one of an enlightening and challenging nature - opening 'a new world: playful, experimental, fragmentary and subversive' - it is also one marked by the fact that it must end. The return of the pilgrim to their 'former mundane existence,' as Turner and Turner (1978: 15) phrase it, is guaranteed. What happens after that, however, is much less clear. That the pilgrim is seen to have 'made a spiritual step forward' and thus to occupy a higher status is accepted, but what of radicals who travelled with a firmly educative and activist agenda (15)? Their previous experiences had often been less than 'mundane,' and their attempts to import lessons from overseas gave them more than 'a special status,' as Scalmer 
(2008: 246) puts it, but an important role in the translation of these ideas into a new context. And nor were the pilgrim's gospels always accepted, with the popular denunciation of radical ideas coming 'to Australia by airmail subscription' from abroad rather than taking on the specificities of local conditions often heard (Gerster \& Bassett 1991: 44-45).

Freney's work on the propagation of ideas around self-management, often known as autogestion, drew heavily on his experiences in Algeria. Upon his return Freney distributed and presented at various leftist conferences a paper entitled 'Workers selfmanagement in Yugoslavia and Algeria' (1969). Algeria's initial heady days of encouraging and supporting the spontaneous will of the people, Freney informed his audience, were short lived. The FLN's left faction - to which Ben Bella and the Trotskyists were allied - soon began to lose power, with a new caste of bureaucrats spouting the language of liberation while consolidating their hold on power. Ben Bella was eventually overthrown in 1965 by conservative figures in the army, who quickly made the state's progressive policies and anti-colonial ideology nothing but rhetoric. Freney, who had left some months before these events, became involved in a global campaign arguing for the release of Ben Bella and spreading the lessons of Algeria's halting attempts at democratic socialism.

Despite the fact that Algeria's experience 'cannot be said to be...definitive [in] testing Self-Management as a global economic and political system,' the recently-returned traveller believed that 'the Algerian experience with all its failings did point to such a possibility' (Freney 1969: 6). Freney's political work then took on firm hues of selfmanagement, presented as workers' control, arguing strongly for it within the Communist Party he was to rejoin in 1970. His arguments met with success, as the party adopted many of these ideas into its reworked, de-Stalinised program. The party organised a conference in 1973 that explored the growing proliferation of work-ins and other such actions across Australia, particularly in the New South Wales Builders Labourers Federation, in an attempt to translate global ideas and practices of workers running their own workplaces into disparate and evolving local contexts (Freney 1991: $325-26){ }^{8}$

\footnotetext{
${ }^{8}$ For a recent discussion of this proliferation of 'work-ins' and self management in Australia, see Burgmann, Jureidini and Burgmann (2012)
} 
The translation of Black Panther Party ideas to Australia was equally complex. McGuinness (1970: 14) described the Panthers he met in Atlanta and New York to be 'the essence to [sic] the black movement,' and not because of their predilection for guns and violence, which '[t]he Australian Press never lets us forget,' but rather the 'one aspect of their activities which is never publicised'-their free breakfast program in Harlem that regularly fed 500 youths a day. When Black Panther groups emerged in Australia in the following year, they took on this firmly community-centred agenda. This was not only due to the lack of a constitutional right to bear arms as in the USA, but also due to the visible success of the Panthers' 'community survival schemes,' which were much easier to transmute into an Australian context and saw the development of long standing medical and legal aid organisations (Lothian 2005: 19097).

Debate was, however, often just as common as agreement: not all of those who went overseas found what they discovered to be either enlightening or useful. Reflecting on his participation in the Atlanta conference, Bob Maza (Gilbert 1973: 117) rebuked the extremes of African-American politics, and those in Australia who sought to emulate them: 'The black situation in the USA made me realise that if our black movement here in Australia is going to be left in the hands of whatever ego-trippers there are around ... then we are going to head the same way that the black Americans did,' a path Maza saw as sectarian, violent and ineffective at facilitating real change. He condemned those who held USA-style 'ultra black ideas' and who rejected working alongside whites: 'these people are certainly going to ensure that we ... isolate ourselves' (Gilbert 1973: 117). Debates in Australian organisations over removing whites from positions of power were thus hotly contested, with acrimonious splits characteristic, rather than the allencompassing upheavals that overcame US groups like the Student Non-Violent Coordinating Committee (SNCC). Other travellers in the group proposed an even broader critique of the usefulness of overseas ideas. Jack Davis (1988: 149-50) argued that the experience of Black Americans, victims of transportation and slavery yet now a significant part of American life, couldn't really relate to Australian Aborigines, who had been in Australia 'since the creation' and had little purchase on public life. Bob Bellear (Gilbert 1973: 115) struck a similar chord, noting how 'the thing is that blacks in Australia...can't equate the problems of this country, the problems of class struggle, the problems of racism in this country with problems in any other part of the world.' 
This was not, however, a rejection of the global as having no role in local affairs - as he related 'while people are being murdered anywhere in the world you must be concerned'—but simply that local concerns must always hold precedence. '[T]he problem ... is getting blacks just to know about each other, in such a vast country as this,' Bellear suggested, and thus overseas experiences should become only a secondary concern.

While Bellear sought to lift local conditions and ideas above what he had witnessed overseas, those who had been to Eastern Europe sought to use these experiences critically to change local realities. An article advertising Laver's 'first public meeting since his return from Europe' in Foco's newsletter captures well the powers a returned pilgrim was imagined to hold. (Foco Newsletter, 20 November 1968). Having glimpsed 'the struggle, by workers and students, to change the whole fabric of Western Society' first hand, he had 'brought back many ideas and evaluations to help us here,' opinions which 'differ ... completely from the attitudes presented in any section of the Australian Press' (Foco Newsletter, 20 November 1968). This glowing advertisement presents Laver as bearing a privileged status and his ideas as holding more value and usefulness than anyone who had not experienced these struggles, but merely read about them in a biased local media. Laver used his privileged status not only to critique Soviet reaction to the Prague Spring, but also to use these criticisms to highlight deficiencies in the Australian party. The CPA was one of the first communist parties to publicly condemn their erstwhile master's actions, yet still harboured deep Stalinist roots, Laver noted. 'The apathy, indifference and fatigue with official rhetoric was as striking in Czechoslovakia as it is in Western "democratic countries",' he recalled, and this condemnation of the languid, bureaucratic reality of life behind the Iron Curtain also constituted a clear jab at local Stalinists. 'It is a difficult thing for members of Communist parties to understand the damage that Stalinist "Marxism" has done,' Laver explained, and while 'in Australia the CPA made that first step...to criticize an action of the USSR' much more was needed. Laver's discourse is reminiscent of one who has experienced 'the truth,' and has come back to disseminate it: 'Until the CPA...makes some real analysis within its forces for the rise of the bureaucracy it will not be able to join in any significant way with the emerging revolutionary forces,' the returned pilgrim prophesied (Laver 1969: 8). SDA was dissolved only a few months after 
Laver's return, replaced with a more radical group that sought to emulate the revolutionary struggle in Europe.

Concomitantly, a spirited debate broke out in the pages of CPA journal Australian Left Review (ALR) after Laver's fellow traveller Susan Burgoyne published a similarly confrontational piece attacking the running of the World Youth Festival in Sofia. Ostensibly about inadequacies in Real Existing Socialism, the discussion was actually part of broader ructions within the party over its direction: remaining loyal to Moscow or taking an independent road open to local conditions. ${ }^{9}$ Firmly placing herself in the later category, Burgoyne (1969: 47) attacked the preparatory committee she had been a member of as 'intent on protecting the festival, not from the right but from those of the left who do not see the Soviet Union in the way that its leaders seek to be seen-as the leaders, teachers and arbitrators.' Such criticism struck a chord of agreement, with many others describing how the Festival showed up deep flaws in the Eastern Bloc and the inability of Soviet bureaucrats to relate to a new generation of global radicals, with one commenting on the festival's slogan that 'there is no solidarity, peace or friendship with dictatorship' (Mortier 1969: 34).

Others, like Burgoyne's fellow International Preparatory Committee delegate Tom Supple, rejected such radical criticisms, lauding the festival as a 'an historic occasion which brought together some fifteen-thousand young people from over 120 countries' in just the bureaucratic language many younger members rejected (1969: 22). Supple's comments in his $A L R$ retort - that the May '68 events in Paris proved not the spontaneous revolutionary potential of working people, but rather that change is impossible 'without the support of the masses and correct political preparations by a communist or Marxist party' (23) — was an additional slight aimed at those who sought to move the CPA away from its traditions as a doctrinaire Marxist-Leninist organisation. This was only the beginning of a much broader debate to overcome the organisation. Its drift away from Soviet hegemony led to an eventual split in 1971, which saw the formation of a pro-Soviet splinter group, the Socialist Party of Australia. Burgoyne (1969: 49) and her fellow reformers remoulded the group into one that saw how 'socialism as it exists in the Soviet Union (or anywhere else) is not sacred,' but instead

\footnotetext{
${ }^{9}$ For further information on this combative period within the CPA, see Russell (1999), O'Lincoln (1985) and Aarons (2010).
} 
sought to understand their place in 'a wide and varied world,' a world made visible through the practice of overseas travel.

\section{Conclusion}

It is widely accepted that we live in a global village where news and ideas spread in a matter of seconds and national boundaries are increasingly redundant. Victor Turner's observations on the importance of pilgrimage, travel and spontaneous communities of understanding within 'liminal' contact zones might, then, seem irrelevant in the face of instant global communication via Facebook or Twitter. The Arab Spring and Occupy Wall Street, after all, spread in a matter of hours and days - not the months or even years a Sixties traveller might take to experience a global hotspot and return with a new 'toolkit' of theories, agendas and practices. But the narratives discussed here deserve more than what E. P. Thompson (1980 [1963]: 12) once so aptly termed 'the condescension of posterity.' That revolutionary ideas could travel via pamphlet, book or-importantly — plane and boat rather than email, personal message or tweet, is a corrective to the 'perpetual present' of media commentators marvelling at the supposedly newfound global interconnectedness of the $21^{\text {st }}$ century.

The movement of diverse activists across seemingly impassable borders of Cold War politics, colonialism and race not only highlights the importance of personal travel to the transmission of ideas and practices, but also paints Australia as an active player in the global Sixties. Far from a 'nation of lotus eaters,' as Australian Prime Minister Harold Holt once characterised the polity, small yet vocal and growing groups of Australians participated in a new type of international engagement during this period. Facing a variety of local problems and questions, these pilgrims sought solutions and answers elsewhere. Denis Freney took his questions about the failings of Soviet bureaucracy and the Australian party that represented it to the unlikely destination of revolutionary Algeria, whose road to democratic socialism seemed to point toward new possibilities. Brian Laver saw the popular eruptions he read and heard of in Europe as holding the key to new forms of activism, while ideas of Black Power emanating from the USA seemed to provide the necessary militancy for a young generation of Indigenous activists increasingly frustrated with the slow pace of change. These activists expressed through their international itinerancy that reading or consuming texts and images of global revolt were sometimes not enough. One needed to drink from the 
proverbial well of rebellious knowledge to understand these ideas not merely as distant theory but as localised practice.

That these travellers encountered a 'liminal moment' is beyond question. Their experiences of spontaneous communities, utopian projects and (for some) illicit desires amply illustrate that a threshold had been crossed into a world where '[o]rdinary rules do not apply' (Scalmer 2008: 246). The fact that Australian radicals could seemingly feel at home with Algerians, Czechoslovakians or Black Americans despite barriers of tradition, culture and language points towards the globalised and shared nature of Sixties protest ideas. But equally, this concept of the pilgrim has its shortcomings. Its lack of temporal reach - a fleeting gap in the normal order of society somewhat akin to Bakhtin's medieval Carnival ${ }^{10}$ —needs adjustment in order to account for the pilgrim's often important pre-history, as well as the difficult and complex translations of new ideas into local contexts afterwards. For these and other trips had a profound impact on the local: Freney's trip to Algeria played a role in enlivening debate around and the practice of workers self-management while the ideals of a global 'third world' revolutionary movement or 'socialism with a human face' were taken up and disputed by socialist and Indigenous activists. Travel, then, served not only to grant confidence and authority, to legitimate and instruct. It also allowed a small group of radicals to enliven in new ways important political debates on the direction of Australian social movements, helping to shape a rebellious period in their history.

\section{Acknowledgements}

An earlier version of this paper was presented at the Australians Abroad conference at the University of Queensland in February 2011. Thanks must go to the organisers and participants, whose advice and criticisms helped to shape it, as well as to Kate Walton and the two anonymous reviewers for their helpful assistance.

\section{Reference List}

Aarons, E. 2000, The Family File. Scribe, Melbourne.

1993, What's Left? Memoirs of an Australian Communist. Allen \& Unwin, St Leonards, NSW.

Bakhtin, M. M. 1968, Rabelais and his World. MIT Press, Cambridge, MA.

Brown, T. S. 2009, “"1968” East and West: Divided Germany as a Case Study in Transnational History,' American Historical Review, vol. 114, no. 1: 69-96.

\footnotetext{
${ }^{10}$ The Carnival, a date of the medieval calendar when normal social and political hierarchies are momentarily overturned, acting as a kind of safety valve for pent up frustrations, is explained in Bakhtin (1968).
} 
Burgmann, V., Jureidini, R. \& Burgmann, M. 2012, 'Doing Without the Boss: Worker's Control Experiments in Australia in the 1970s,' Labour History, no. 103: 103-22.

Burgoyne, S. 1969, 'The World Youth Festival,' Australian Left Review, January-February: 45-49.

Clark, J. 2008, Aborigines and Activism: Race and the coming of the Sixties to Australia. University of Western Australia Press, Crawley, WA.

Davis, J. 1988, Jack Davis: A Life-story. DENT, Melbourne.

d'Avigdor, L. 2011, 'Let the Lunatics Run Their Own Asylum: Participatory Democracy at the University of Sydney, 1960-1979’ B.A. Honours Thesis, University of Sydney.

de Costa, R. 2006, A Higher Authority: Indigenous Transnationalism and Australia. University of New South Wales Press, Sydney.

Fitzpatrick, S. \& Rasmussen, C. (eds) 2008, Political Tourists: Travellers from Australia to the Soviet Union in the 1920s to the 1940s. Melbourne University Press, Carlton, Vic.

Foco Newsletter. 1968, vol. 1, no. 38, 20 November.

Foley, G. 2001, 'Black Power in Redfern, 1968-72,' B.A. Honours Thesis, University of Melbourne. Online, available: http://www.kooriweb.org/foley/essays/essay_1.html [Accessed 2 April 2011].

Frazier, R. T. P. 2006, 'The Congress of African People: Baraka, Brother Mao and the Year of '74,' Souls, vol. 8 , no. 3: $142-59$.

Freney, D. 1969, 'Workers Self-management in Yugoslavia and Algeria,' unpublished paper. 1991, A Map of Days: Life on the Left. William Heinemann, Port Melbourne, Vic.

Gerster, R. \& Bassett, J. 1991, Seizures of Youth: The Sixties and Australia. Hyland House, Melbourne.

Gilbert, K. 1973, Because a White Man'll Never Do It. Angus and Robertson, Sydney.

Gildea, R., Mark, J. \& Pas, N. 2011, 'European Radicals and the 'Third World': Imagined Solidarities and Radical Networks, 1958-73,' Cultural and Social History, vol. 8, no. 4: 449-72.

Gosse, V. 1993, Where the Boys Are: Cuba, Cold War America and the Making of a New Left. Verso, London.

Horne, D. 1980, Time of Hope: Australia 1966-72. Angus and Robertson, Sydney.

Hyde, M. 2010, All Along the Watchtower: Memoir of a Sixties Revolutionary. Vulgar Press, Carlton, Vic.

Jobs, R. I. 2009, 'Youth Movements: Travel, Protest and Europe in 1968,' American Historical Review, vol. 114 , no. 2: 376-404.

Joseph, P. E. 2001-2002, 'Where Blackness is Bright? Cuba, Africa and Black Liberation During the Age of Civil Rights,' New Formations, no. 45: 111-124.

Klimke, M. 2010, The Other Alliance: Student Protest in West Germany \& The United States in the Global Sixties. Princeton University Press, Princeton.

Krekola, J \& Mikkonen, S. 2011, 'Backlash of the Free World: The US presence at the World Youth Festival in Helsinki, 1962,' Scandinavian Journal of History, vol. 38, no. 2: 230-55.

Kruger, P. 1970, 'A Year in the Revolutionary Education,' in Aborigines Visit the USA: Report on trip by Five Aborigines to Congress of African People and United Nations. ABSCHOL, Melbourne: 3139.

Laver, B. 1969, Czechoslovakia ... A Social Crisis: Bureaucracy or People's Control? Revolutionary Socialist Alliance, Brisbane. interviewed by A. Stafford 2001. 6 November, Andrew Stafford Collection. UQFL440, Fryer Library, University of Queensland, St Lucia.

Lionnet, F. \& Shih, S. (eds) 2005, Minor Transnationalisms. Duke University Press, Durham, NC.

Lothian, K. 2002, 'A Blackward Step is a Forward Step': Australian Aborigines and Black Power, 1969 1972. Monash University, Melbourne.

2005, 'Seizing the Time: Australian Aborigines and the Influence of the Black Panther Party, 1969-1972,' Journal of Black Studies, vol. 34, no. 4, 179-200.

Mackay, H. 2009, 'Australia: A Nation of Lotus-Eaters,' in 1968: Memories and Legacies of a Global Revolt, (eds) M. Klimke \& P. Gassert. German Historical Institute, Washington.

McGuinness, B. 1970, 'Report by Bruce B. McGuinness Director Administrative Officer A.A.L.,' in Aborigines Visit the USA: Report on Trip by Five Aborigines to Congress of African People and United Nations. ABSCHOL, Melbourne: 6-18.

Mortier, N. 1969, 'World Youth Festival-Another View,' Australian Left Review, August-September: 34-35.

Mortimer, R. 1976, 'The Benefits of a Liberal Education,' Meanjin, vol. 35, no. 2: 115-26.

O'Lincoln, T. 1985, Into the Mainstream: The Decline of Australian Communism. Stained Wattle Press, Sydney.

O’Neill, D. 1969, 'The Growth of the Radical Movement,' Semper Floreat, vol. 39, no. 2, 17 March: 916. 
Piccini, J. 2010, ““Australia’s Most Evil and Repugnant Nightspot”: Foco Club and Transnational Politics in Brisbane's '68,' Dialogues E-Journal, vol. 1, no. 8: 1-17.

Prentice, J. 2007, 'Remembering the Brisbane Protests, 1965-72: The Civil Liberties Movement,' Queensland Review, vol. 14, no. 1: 25-37.

Prince, S. 2006, 'The Global Revolt of 1968 and Northern Ireland,' The Historical Journal, vol. 49, no. 3: 851-75.

Rootes, C. 1969, 'Australian Student Radicals: The Nature and Origins of Dissent.' B.A. (Hons) Thesis, University of Queensland.

Russell, L. 1999, 'Today the Students, Tomorrow the Workers! Radical Student Politics and the Australian Labour Movement 1960-1972.' PhD Thesis, University of Technology Sydney.

Scalmer, S. 2002, Dissent Events: Protest, the Media and the Political Gimmick in Australia. University of New South Wales Press, Sydney. 2008, 'Turner Meets Gandhi: Pilgrimage, Ritual, and the Diffusion of Nonviolent Direct Action,' in Victor Turner and Contemporary Cultural Performance, (ed.) G. St John. Berghahn Books, London: 242-57. 2011, Gandhi in the West: The Mahatma and the Rise of Radical Protest. Cambridge University Press, Cambridge.

Sobocinska, A. 2010, 'People's Diplomacy: Australian Travel, Tourism and Relations with Asia, 19412009.' PhD Thesis, University of Sydney.

Society for Democratic Action leaflet. 1966, In Geoffrey Dalton-Morgan, Miscellaneous Publications of the Society for Democratic Action. F 3235, Fryer Library, University of Queensland, St Lucia.

Student Guerrilla, 1968a, Vol. 1, No. 1, 19 March: 1. 1968b, Vol. 1, No. 5, 16 April: 1.

Supple, T. 1969, 'Festival defended,' Australian Left Review, April-May: 22-23.

Taylor, R. 1968, 'World Youth Festival,' Lot's Wife, 1 October: 9.

Thompson, E.P. 1980 [1963], The Making of the English Working Class. Penguin Books, Harmondsworth, UK.

Turner, E. \& Turner, V. 1978, Image and Pilgrimage in Christian Culture: Anthropological Perspectives. Columbia University Press, New York.

Turner, V. 1982, 'Liminal to Liminoid, in Play, Flow, Ritual: An Essay in Comparative Symbology,' in From Ritual to Theatre: The Human Seriousness of Play. Performing Arts Journal Publications, New York: 20-60.

Varon, J. 2004, Bringing the War Home: The Weather Underground, The Red Army Faction and Revolutionary Violence in the Sixties and Seventies. University of California Press, Berkeley, CA.

Vietnam Protest Week leaflet. 1966, In Geoffrey Dalton-Morgan, Miscellaneous Publications of the Society for Democratic Action. F 3235, Fryer Library, University of Queensland, St Lucia.

Wilkins, F. C. 2006, 'Beyond Bandung: The Critical Nationalism of Lorraine Hansberry,' Radical History Review, no. 95: 191-210.

Worker-Student Alliance leaflet, Melbourne University. 1973, Contained in Charles Dixon, vol. 2, A6119 3647, National Archives of Australia, Canberra.

Wu, J. T. C. 2007, 'Journeys for Peace and Liberation: Third World Internationalism and Radical Orientalism during the U.S. War in Vietnam,' Pacific Historical Journal, vol. 76, no. 4: 575-84.

Yeats, K. 2010, 'Australian New Left Politics: 1956-1972.' PhD Thesis, University of Melbourne.

Young, C. A. 2006, Soul Power: Culture, Radicalism, and the Making of a US Third World Left. Duke University Press, Durham, NC. 